\title{
Reshoring to the EU and the USA: problems, trends and prospects
}

\author{
Veronika Yu. Chernova \\ The State University of Management \\ 99 Ryazanskii Ave., Moscow, 109542, Russian Federation
}

\begin{abstract}
Reshoring is recognized as one of the tools to achieve the goal set in Western countries to restore the role of manufacturing in the economy, its "renaissance", stimulate innovation and increase employment. This article analyzes current trends and prospects for reshoring. Obstacles to the successful relocation of Western companies' production capacities to maternal jurisdiction were identified, the key role of which was played by the US protectionist policy and the escalation of trade conflicts. As a result, after increasing the cases of reshoring in previous years, in 2018-2019, the process of moving production facilities of western companies to other countries of Southeast Asia at lower costs received an additional impetus. It is concluded that the state policies of countries aimed at reviving their industry and the technology of the fourth industrial revolution have a significant impact on the change in the position of individual countries in the international division of labor, which gives an opportunity for "catching countries" to develop the economy and improve their position in the world trade.
\end{abstract}

Keywords: reshoring, reindustrialization, value chains, the fourth industrial revolution technologies, protectionism, trade wars, trade policy, reshoring strategies policies

\section{Introduction}

Reshoring, as one of the forms of reindustrialization, restoring the role of manufacturing in the economy, its "renaissance", stimulating innovation and employment growth, has attracted growing attention of scientists and politicians in recent years.

The governments of developed countries are developing measures to promote reshoring in order to increase national industrial production and increase employment. For example, the European Parliament adopted a resolution on the reindustrialization of Europe to promote competitiveness and sustainability, which noted the positive impact of resharing initiatives to support the traditional industrial regions of the EU. In the policy documents "A Stronger European Industry for Growth and Economic Recovery" (October 2012) and "For a European Industrial Renaissance" (January 2014), proclaiming the EU's goal to reverse the declining share of production in GDP, reshoring is recognized as one of the means achieving the goal.

At national levels, several European countries have also taken measures to promote resharing strategies. France is quite active in support of reshoring strate-

(C) Chernova V.Yu., 2020

(c) This work is licensed under a Creative Commons Attribution 4.0 International License https://creativecommons.org/licenses/by/4.0/ 
gies, where about $60 \%$ of the companies that took the initiative to transfer their production capacities back to France received support from the central government and/or local authorities. In the Netherlands, the Ministry of Social Welfare and Employment has created a special incentive fund ( $€ 600$ million) to support job creation in the resharing process. In Italy, government support is provided both at the state and regional levels. In addition, the three largest economies of the EU (France, Germany and Italy) have combined their key industry digitalization initiatives the German Platform Industry 4.0, the French Alliance Industrie du Futur and the Italian Piano Industria 4.0 initiative, agreed on trilateral cooperation and have developed a roadmap to support and strengthen digitalization processes in their productive sectors, as well as to advance the efforts of all EU countries in this area.

In 2018, in the USA, the corporate income tax was drastically reduced (from 35 to $21 \%$ ), as well as the tax on funds that are returned to the country from the activities of companies abroad (up to $15.5 \%$ for cash, and for non-cash - up to $8 \%$ instead of the previous 35\%). Additionally, tax deductions for capital costs have been introduced for companies.

In addition, the United States has an Import Substitution Program (ISP), an Economic Development Program, and a Skilled Workforce Development Program to support firms in evaluating and implementing re-settlement decisions to replace local manufacturing imports developed by the non-governmental organization Reshoring Initiative.

The study of trends, problems and prospects of reshoring is of practical interest to researchers from different countries in connection with the increasing role of value chains, the involvement of developing countries and countries with economies in transition, increased competition in world markets, which determines the relevance of this article. The aim of the study was to identify current trends in the development of reshoring processes, their features, problems and prospects.

\section{Methods}

To achieve the goal, we used such methods of scientific knowledge as system analysis, logic, deduction and induction, observation, comparison, generalization, and statistical processing of empirical data.

The basis of the study of current trends, problems and prospects of resharing was official EU statistics - the EU Agency for the Improvement of Living and Working Conditions (Eurofound) and the non-governmental organization Reshoring Initiative USA, as well as data from periodicals, publications of various authors, including those posted on the Internet resources dedicated to the study of reshoring in the EU and the USA.

\section{Literature review}

In recent years, the topic of reshoring has been given increasing attention by researchers in different countries. A resharing strategy reflecting the changing nature of the global functioning of the global manufacturing industry was studied in the work of V. Kondratyev (Kondratyev, 2017), where he notes that both developed and developing countries began to concentrate production more and more in recent years, there is a tendency to place production in regional and local hubs, moving them to low-cost coun- 
tries. Initially, reshoring was considered the correction of a previously committed managerial mistake in transferring production capacities to third countries without considering all costs and risks (Kinkel, Maloca, 2009). More recent studies have shown that decisions to return production capacities are often made in response to changes in the external environment (development of new technologies, increased protectionism, rising labor costs in China, etc.). Currently, there is a wide variety of reshoring motives (see Stentof et al., 2016; Fratocchi et al., 2016; Srai, Ané, 2016). Particular attention in reshoring studies is given to the role of technologies of the fourth industrial revolution (Ancarani, Mauro, 2018; Kheyfets, 2018; Kheyfets, 2019). A significant contribution to the development of the theoretical foundations of reshoring was made by De Baker et al. (De Backer, Menon, Desnoyers-James, Moussiegt, 2016), the research work of which focuses on the public policies of different countries, carried out to support reshoring. The article notes that countries use a wide range of tools from the simple provision of information to financial assistance and, in some cases, government support measures for re-settlement companies create competitive advantages for them in the national market, while putting other national companies in a less favorable position, which does not contribute increased industry efficiency.

\section{Reshoring in the EU and the USA}

In the literature on the problems of reshoring, in addition to the term "reshoring", such concepts as "back shoring" and "nearshoring" are used. At the same time, in some works, reshoring is interpreted as moving production facilities to the country of jurisdiction of the parent company, in others - as any change in their location. Nearshoring is usually referred to as the transfer of offshore production facilities to a nearby country, located next to the country of registration of the parent company. Back shoring refers to the transfer of production capacities from distant countries to the parent jurisdiction, while the terms "back shoring" and "reshoring" are often used synonymously. In addition, back shoring and nearshoring, regardless of the form and structure of ownership, can be carried out within the company itself or outsourced to independent suppliers (Kondratyev, 2017). The dominant strategy for the return of production capacities among EU companies is back shoring $(92.4 \%$ of cases for the period from 2014 to 2018$)$, while the nearshoring strategy was used only in $5.1 \%$ of cases.

Currently, the most common motivations for re-resolving EU companies are factors related to business reorganization and the desire to reduce production costs by approaching consumers and suppliers of resources, reducing labor costs, logistics, costs of product quality and its (Table 1.). At the same time, among the motives of reshoring, there are factors of the influence of technologies of the fourth industrial revolution - automation of production, the availability of know-how in the parent company, the implementation of strategies for the introduction of innovations, and the availability of government support measures.

Unlike European companies, government incentives for reshoring and "patriotic" sentiments (the "Made in the USA" brand, influence on the domestic economy) have a key influence on the decisions of American businesses to return their production capacities. For European companies, the motto "Made in..." was decisive only for Italian clothing manufacturers. 
Motivation for reshoring to the EU and the USA

\begin{tabular}{|c|c|c|c|}
\hline EU reshoring motives & $\begin{array}{l}\text { Number } \\
\text { of cases }\end{array}$ & USA reshoring motives & $\begin{array}{l}\text { Number } \\
\text { of cases }\end{array}$ \\
\hline Global reorganization of a company & 61 & Government incentive reshoring & 844 \\
\hline Product delivery time to consumer & 55 & Proximity to customers/markets & 818 \\
\hline $\begin{array}{l}\text { Automation of the manufacturing pro- } \\
\text { cess }\end{array}$ & 51 & $\begin{array}{l}\text { Availability of skilled labor and its hig- } \\
\text { her learning abilities }\end{array}$ & 673 \\
\hline Low quality offshore product & 48 & Image/brand "Made in the USA" & 615 \\
\hline Proximity to customers & 43 & Supply chain optimization & 581 \\
\hline The effect of "Made in..." & 40 & Impact on the domestic economy & 408 \\
\hline Know-how & 30 & Infrastructure & 352 \\
\hline $\begin{array}{l}\text { Implementation of strategies based on } \\
\text { product/process innovation }\end{array}$ & 28 & Product delivery time to consumer & 344 \\
\hline Production flexibility & 27 & Automation/new technology & 274 \\
\hline Change in total supply costs & 26 & Higher labor performance & 230 \\
\hline Unused production capacity & 26 & Customer service improvement & 208 \\
\hline Logistics costs & 24 & $\begin{array}{l}\text { Synergy from the combination of pro- } \\
\text { duction and } R \text { \& D }\end{array}$ & 204 \\
\hline Reduced labor costs & 19 & $\begin{array}{l}\text { US natural gas/chemicals/electricity } \\
\text { prices }\end{array}$ & 172 \\
\hline Economic crisis & 18 & $\begin{array}{l}\text { Underutilization of production capacity } \\
\text { in an offshore country }\end{array}$ & 141 \\
\hline Customer service improvement & 17 & $\begin{array}{l}\text { Lean manufacturing/other business } \\
\text { process improvement methods }\end{array}$ & 134 \\
\hline State support for reshoring & 15 & $\begin{array}{l}\text { The presence of a developed network } \\
\text { of wholesale and retail }\end{array}$ & 131 \\
\hline Proximity to resource providers & 13 & Lower raw material costs & 128 \\
\hline Fidelity to the native country & 11 & Production flexibility & 115 \\
\hline $\begin{array}{l}\text { High costs of quality and its control in } \\
\text { an offshore country }\end{array}$ & 10 & 3D printing/additive manufacturing & 29 \\
\hline
\end{tabular}

Source: Eurofound (2019). Reshoring in Europe: Overview 2015-2018. Publications Office of the European Union, Luxembourg. Retrieved from https://www.eurofound.europa.eu/publications/report/2019/ reshoring-in-europe-overview-2015-2018 (accessed: 20.12.2019); Reshoring Initiative USA (n.d.). Reshoring initiative: Bringing manufacturing back home. Retrieved from http://www.reshorenow.org (accessed: 20.12.2019).

It should be noted that for the period from 2014 to 2019, the motives for the reshoring of companies in the EU countries have undergone changes. So, in 2014-2017. For European companies, government support, strategies to reduce production costs (labor costs, logistics, procurement, etc.), the economic crisis and innovative strategies were the determining motives for transferring their production capacities to their home country. In 2018, the factor of state support began to play a significantly smaller role, and the main motivation for reshoring by European companies was attributed to the low quality of products in offshore countries and the high costs of its provision and control, as well as to some increase in patriotic moods (loyalty to their native country) (Figure 1).

In European countries, the decision on reshoring is most often made by companies in low- and medium-tech industries (clothing and food) (Table 2), while among the American companies that have returned their production facilities back to the USA, a significant proportion industries are high-tech (computers, electronic products, electrical equipment, devices and components) and medium-tech highlevel industries (transport equipment). 


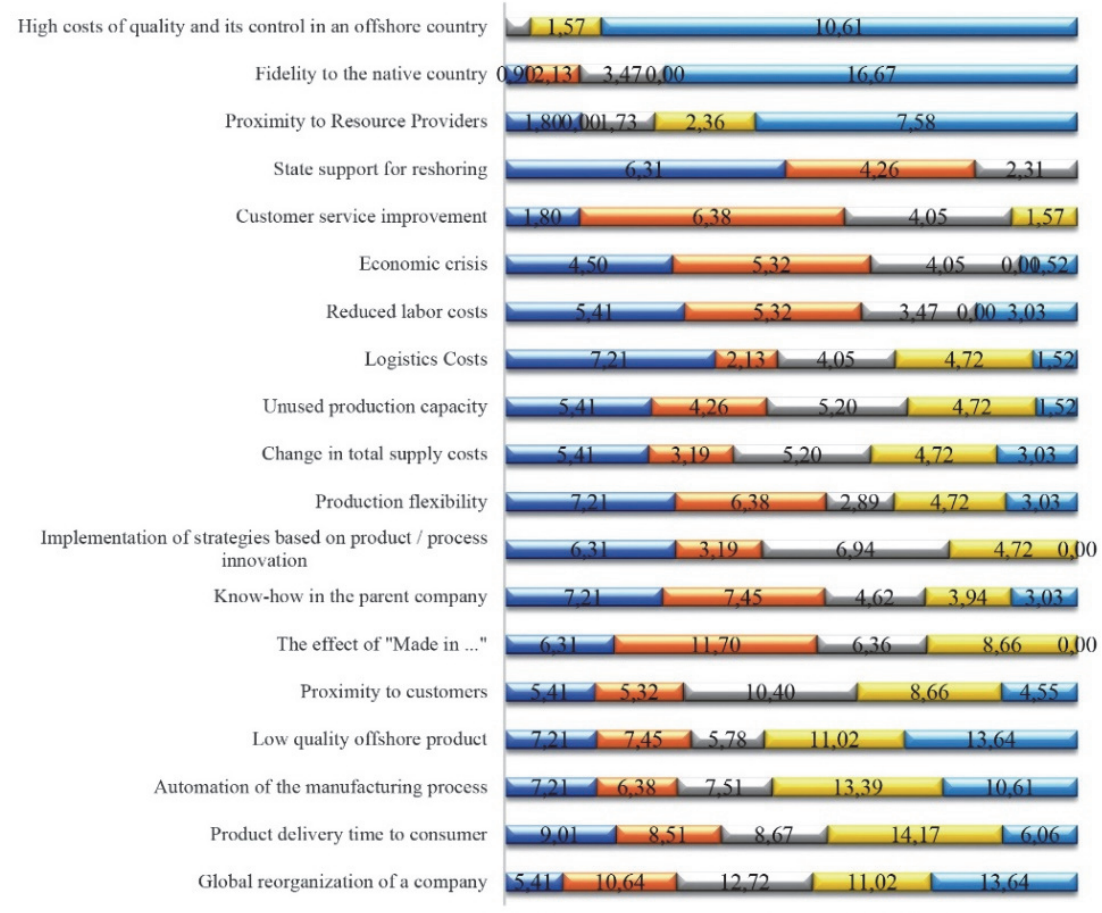

$\begin{array}{lllllllllllllllll}0 \% & 10 \% & 20 \% & 30 \% & 40 \% & 50 \% & 60 \% & 70 \% & 80 \% & 90 \% & 100 \%\end{array}$

$\square 2014 \square 2015 \square 2016 \square 2017 \square 2018$

Figure 1. Changes in the motivation for reshoring EU companies in 2014-2018

Source: estimated by author based on: Eurofound. (2019). Reshoring in Europe: Overview 2015-2018. Publications Office of the European Union, Luxembourg. Retrieved from https://www.eurofound.europa.eu/ publications/report/2019/reshoring-in-europe-overview-2015-2018 (accessed: 20.12.2019).

Sectoral structure of reshoring in the EU and the USA

Table 2

\begin{tabular}{|c|c|c|c|c|c|}
\hline \multirow{2}{*}{ EU } & \multicolumn{2}{|c|}{ Number of cases } & \multirow{2}{*}{ USA } & \multicolumn{2}{|c|}{ Number of cases } \\
\hline & units & $\%$ & & units & $\%$ \\
\hline Manufacture of wearing apparel & 29 & 17,3 & Transport equipment & 772 & 16,6 \\
\hline Food production & 24 & 14,3 & Clothing and textiles & 560 & 12,0 \\
\hline Manufacture of machinery and & 20 & 119 & Manufacture of fabricated metal & 419 & 90 \\
\hline Manufacture of computer, & 20 & 11,9 & Computers, electronic products & 416 & 8,9 \\
\hline electronic and optical products & 19 & 11,3 & Chemicals & 409 & 8,8 \\
\hline Production of electrical equip- & & & Electrical equipment, devices & & \\
\hline ment & 17 & 10,1 & and components & 375 & 8,0 \\
\hline Manufacture of other transport & & & Plastic and rubber products & 351 & 7,5 \\
\hline equipment & 17 & 10,1 & Other industries & 326 & 7,0 \\
\hline Manufacture of fabricated met- & & & Cars & 269 & 5,8 \\
\hline al products, except machinery & & & Furniture and related products & 169 & 3,6 \\
\hline and equipment & 13 & 7,7 & Food and drink & 132 & 2,8 \\
\hline Manufacture of cars, trailers & & & Medical equipment and supplies & 124 & 2,7 \\
\hline and semi-trailers & 12 & 7,1 & Wood and paper & 116 & 2,5 \\
\hline Other production & 9 & 5,4 & Manufacture of fabricated metal & & \\
\hline \multirow{3}{*}{ Furniture manufacture } & 8 & 4,8 & products & 113 & 2,4 \\
\hline & & & Non-metallic mineral products & 90 & 1,9 \\
\hline & & & $\begin{array}{l}\text { Energy, gasoline and coal pro- } \\
\text { ducts }\end{array}$ & 19 & 0,4 \\
\hline
\end{tabular}

Source: Eurofound. (2019). Reshoring in Europe: Overview 2015-2018. Publications Ofice of the European Union, Luxembourg. Retrieved from https://www.eurofound.europa.eu/publications/report/2019/ reshoring-in-europe-overview-2015-2018 (accessed: 20.12.2019); Reshoring Initiative USA (n.d.). Reshoring initiative: Bringing manufacturing back home. Retrieved from http://www.reshorenow.org (accessed: 20.12.2019). 


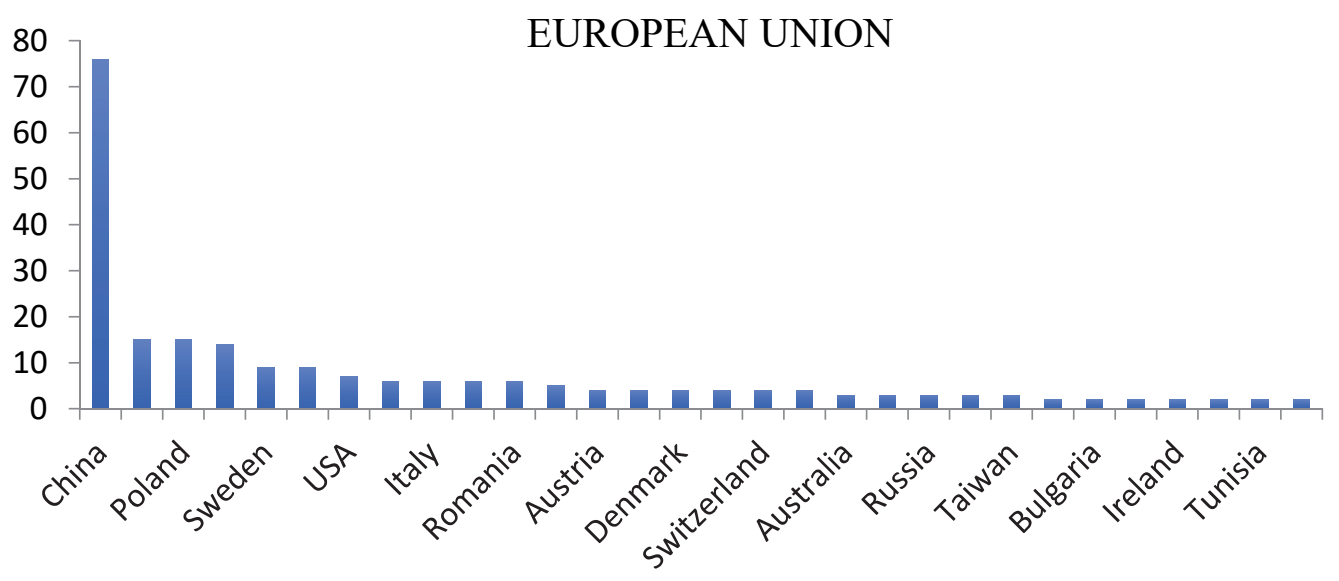

UNITED STATES

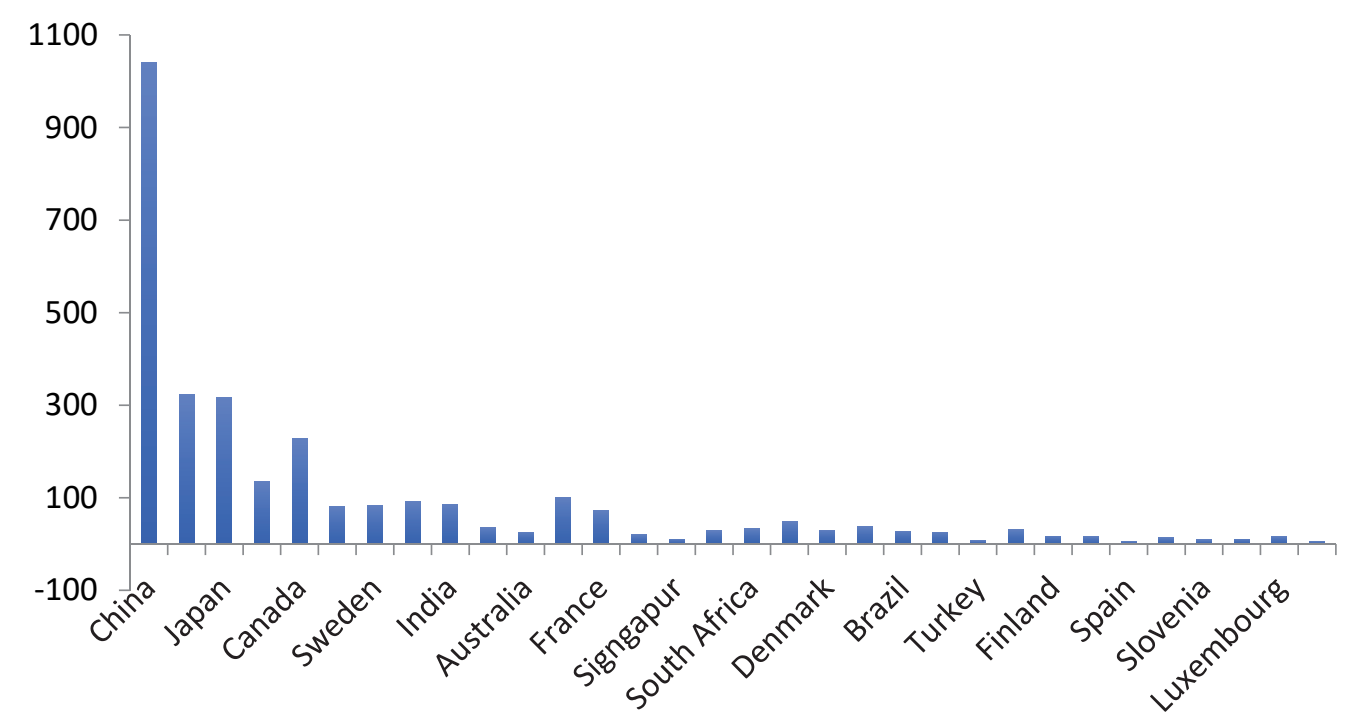

Figure 2. The number of cases of reshoring companies in the EU and the USA in 2014-2018

Source: Eurofound. (2019). Reshoring in Europe: Overview 2015-2018. Publications Ofice of the European Union, Luxembourg. Retrieved from https://www.eurofound.europa.eu/publications/report/2019/ reshoring-in-europe-overview-2015-2018 (accessed: 20.12.2019); Reshoring Initiative USA (n.d.). Reshoring initiative: Bringing manufacturing back home. Retrieved from http://www.reshorenow.org (accessed: 20.12.2019).

In general, the resharing strategy is most attractive for companies in those industries where new production in a developed country has significant competitive advantages. This includes the production of goods whose shipping costs are high; production of goods with a short production cycle requiring ultra-precise just-in-time logistics; production subject to frequent design changes; production requiring a high level of quality; the production of goods using patents and copyrights, the observance and protection of which are of utmost importance; industries sensitive to robotics and automation.

As for the countries from which the production facilities are being withdrawn, both American and European companies mainly return from China (1042 and 76 cases 
of reshoring, respectively). In addition, American companies return from Germany (323 cases of reshoring), Japan (317 cases of reshoring), Canada (229 cases of reshoring), and the production capacities of European companies partially or completely move from other European countries (Fratocchi et al., 2015) (Figure 2).

\section{Reverse or slowdown of reshoring processes in developed countries as a reaction to protectionism policy}

Even though the Reshoring Initiative is convincing that in the coming years companies will be more motivated to participate in reshoring, statistics show the opposite. So, in the EU, the number of cases of reshoring after a significant increase in 2016-2017 in 2018 decreased by 1.6 times, and the number of companies that decided to transfer their production capacities from third countries decreased by 1.3 times (Figure 3 ).

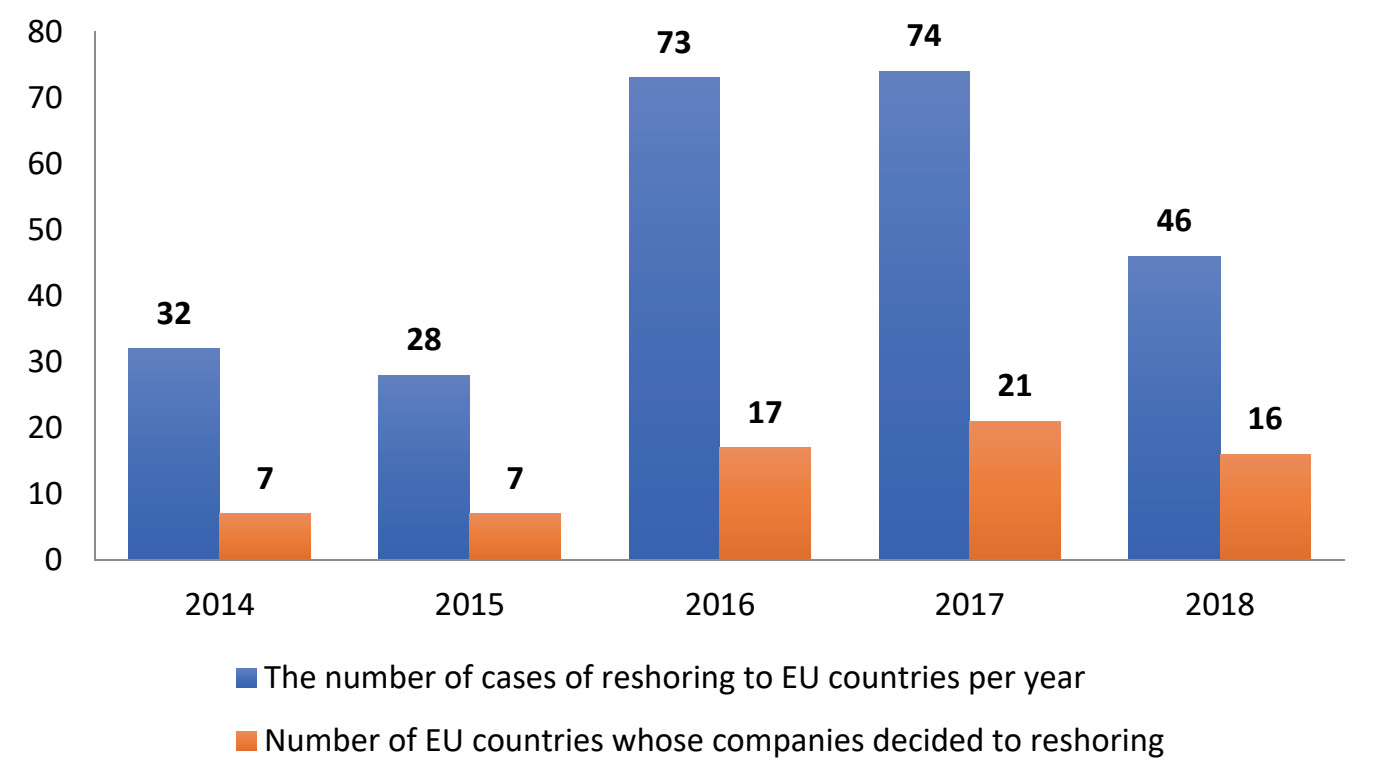

Figure 3. Change in cases of reshoring companies in EU countries in 2014-2018

Source: Eurofound (2019). Reshoring in Europe: Overview 2015-2018. Publications Office of the European Union, Luxembourg. Retrieved from https://www.eurofound.europa.eu/publications/report/2019/ reshoring-in-europe-overview-2015-2018 (accessed: 20.12.2019).

Moreover, at the end of 2019, cases of the return of companies moved to developed countries back to low-cost countries became known. So, the Adidas concern, which in 2017 partially returned the production of sneakers from Asia to Germany and the United States, already at the end of 2019 announced the closure of these industries and their return to Asia. The "Speed factories" project, which became a symbol of the return and revival of industries previously transferred to Asia, and a clear example of the implementation of Industry 4.0 technologies, ended three years later.

Businesses that Adidas calls Speed factories use automated sneaker technology. Adidas hoped to bring shoe production closer to consumers and reduce emissions during transportation, but now decides to use its automated technology 
in Vietnam and China. According to experts, this decision is due to the fact that 1) the main suppliers and the main production are located in the Asian region; 2 ) in Germany, higher production costs, in particular energy and labor costs, since robotic production is more energy intensive and does not completely exclude human participation; 3 ) in developed countries there is a shortage of skilled workers; 4) there was a more rapid catching up by Asian countries of their technological backlog than could be expected in 2016, when a decision was made on reshoring. At the same time, according to other experts, the decision to return to Asia may be premature and the Adidas concern did not have the patience to wait until its German and American factories began to operate at full capacity and production would be in demand in Europe and America.

American business, despite the efforts of the Trump administration to promote reshoring, switching to Chinese tariffs or tax breaks for companies, does not transfer production operations back to the United States, instead preferring to diversify its activities in other low-cost countries. According to A.T. The Kearney Reshoring Index, calculated as the share of imports in domestic production, has been declining for the third year in a row, while US manufacturing growth has lagged behind low-cost imports, with a notable reduction in imports from China. In general, the actions of D. Trump are of concern to American business and often contradict the interests of American manufacturers. The increase in import duties on steel (by 25\%) and aluminum (by 10\%) in order to protect American producers has dealt a blow to those American companies that import metals for their American production. The reciprocal increase in tariffs on the part of the EU for the finished products of American manufacturers led to the fact that they received a double blow and were forced to transfer their production capacities to countries with low costs. For example, Harley-Davidson in 2018 announced the transfer of production of motorcycles intended for the European market to Thailand. Among other companies that relocated partially or fully their production facilities to Southeast Asia, Panasonic (from the United States to Malaysia), footwear and accessories manufacturer Steven Madden (from China to Cambodia).

There is resistance from American firms and the requirement to transfer production capacities back to the United States, since this requirement does not coincide with their economic interests (Savinov et al., 2019). For example, Ford said that it was not profitable for it to produce a Focus Active model in the United States, and given the forecast for annual sales below 50,000, and Apple, most of whose products, including the iPhone and iPad, are manufactured in China, indicated that it might be forced to raise the price of its products due to tariff increases. However, later, Apple Inc announced the optimization of the value chain of its products and asked its main suppliers (Foxconn, Pegatron Corp, Wistron Corp, Quanta Computer Inc, Compal Electronics Inc, etc.) to evaluate the financial consequences of moving $15-30 \%$ of their production capacity from China to Southeast Asia (India, Vietnam, Indonesia and Malaysia), as well as Mexico.

It should be noted that the transfer of production capacities from China to Southeast Asian countries with lower production costs, primarily to Vietnam, has been going on for several years. Examples of companies that have increased their share of output in Vietnam over the past ten years by moving them from China are 
Nike and Adidas. But there are examples of the transfer of production capacities from China to Vietnam as a result of trade tensions between China and the United States. The main reasons for choosing Vietnam for the transfer of production capacities are lower labor costs, proximity to supply chains in Southeast Asia and a favorable investment climate.

Another popular destination for transferring production capacities from the warring between the United States and China is Mexico, which is increasingly seen as a refuge from trade disputes. As a result, Mexico's exports to the United States in 2018 increased by $\$ 28$ billion, which is $10 \%$ more than in 2017 and is the highest growth rate of Mexican exports over the past seven years. Moreover, Mexico is chosen not only by American companies fleeing China (GoPro), but also Chinese manufacturers exporting their products to the USA (Fuling Global Inc) as a place for placing production capacities.

Thus, the lack of a stable and predictable business environment as a result of the protectionist policies of D. Trump and his trade wars is an obstacle to the more successful implementation of reindustrialization through reshoring.

A significant reason for the refusal to transfer its production capacities back to the USA is the unpreparedness of the American labor market for such largescale transformations. One of the main factors holding back US production growth is the lack of skilled labor. The number of vacant jobs in production has been growing for five years and in 2018 averaged over 0.46 million.

\section{Conclusion}

The economic benefits of manufacturing in low-cost countries continue to play a decisive role in choosing a new location for production facilities. The increase in the cost of production in China, including due to an increase in labor costs, and the process of moving production facilities of Western companies to other countries in Southeast Asia at lower costs, has been going on for several years. However, as a result of the aggravation of trade conflicts, this process received an additional impetus.

Although, according to V. Zagashvili (Zagashvili, 2017), the intentions and actions of D. Trump, at first glance, coincide with the tendency of developed countries to re-industrialize and transfer production capacities of industrial enterprises back to these countries, protectionist policies and the escalation of trade conflicts have become key an obstacle to the successful implementation of reshoring, reducing the investment attractiveness of some developed countries.

An important obstacle to the return of manufacturing capacities of manufacturing companies to developed countries is the insufficient efforts of these countries to increase the number of skilled workers with the necessary competencies to work with the technologies of the fourth industrial revolution. The role of the shortage of skilled workers is especially intensified in the context of a rapid reduction in technological backwardness in some developing countries.

In general, we can conclude that the state policies of countries aimed at reviving their industry and the technology of the fourth industrial revolution have a significant impact on international trade, which leads to a change in the position of individual countries in the system of the international division of labor. As a re- 
sult, the so-called "catching up countries" got a new chance to improve their positions in the international division of labor, which would be an unforgivable mistake to miss, especially since the speed of such changes is steadily increasing.

\section{References}

Ancarani, A., \& Di Mauro, C. (2018). Reshoring and Industry 4.0: How often do they go together? IEEE Engineering Management Review, 46(2), 87-96.

BMWI. (2019). Shared Action Plan Industrie du Futur / Industrie 4.0 / Industria 4.0 in FranceGermany - Italy. Retrieved from https://www.plattform-i40.de/PI40/Redaktion/EN/ Downloads/Publikation/shared-actionplan-fr-de-it.html (accessed: 20.12.2019).

De Backer, K., Menon, C., Desnoyers-James, I. \& Moussiegt, L. (2016). Reshoring: myth or reality? OECD Science, Technology and Industry Policy Papers No. 27. OECD Publishing, Paris. Retrieved from https://www.oecd-ilibrary.org/science-and-technology/ reshoring-myth-or-reality_5jm56frbm38s-en (accessed: 20.12.2019).

EC. (2012). A Stronger European Industry for Growth and Economic Recovery. Industrial Policy Communication Update. Retrieved from https://eur-lex.europa.eu/LexUriServ/ LexUriServ.do?uri=COM:2012:0582:FIN:EN:PDF (accessed: 20.12.2019).

EC. (2014). For a European Industrial Renaissance. Retrieved from https://eur-lex.europa.eu/ legal-content/EN/TXT/PDF/?uri=CELEX:52014DC0014\&from=EN (accessed: 20.12.2019).

Eurofound. (2019). Reshoring in Europe: Overview 2015-2018. Publications Office of the European Union, Luxembourg. Retrieved from https://www.eurofound.europa.eu/ publications/report/2019/reshoring-in-europe-overview-2015-2018 (accessed: 20.12.2019).

Fratocchi, L., Ancarani, A., Barbieri, P., Di Mauro, C., Nassimbeni, G., Sartor, M. et al (2016). Motivations of manufacturing reshoring: An interpretative framework. International Journal of Physical Distribution \& Logistics Management, 46(2), 98-127.

Fratocchi, L., Barbieri, P., Ancarani, A., Di Mauro, C., Troiano, A., Vignoli, M. et al. (2015). Manufacturing back- and near-reshoring: A comparison of European and North American companies. In J. Stentof, A. Paulraj, G. Vastag (Eds.), Research in the decision sciences for global supply chain network innovations: Best papers from the 2014 Annual Conference (pp. 107-128). Pearson Education Inc., Old Tappan, NJ.

Hejfec, B.A. (2018). Metamorfoza ekonomicheskoj globalizacii [Metamorphosis of economic globalization]. Moscow, Institut ekonomiki RAN Publ. (In Russ.)

Hejfec, B.A. (2019). Novye ekonomicheskie megapartnerstva i Rossiya [New Economic Megapartnerships and Russia]. Saint Petersburg, Aletejya Publ. (In Russ.)

Kinkel, S., \& Maloca, S. (2009). Drivers and antecedents of manufacturing offshoring and backshoring: A German perspective. Journal of Purchasing and Supply Management, $15(3), 154-165$.

Kondrat'ev, V. (2017). Reshoring kak forma reindustrializacii [Reshoring as a form of reindustrialization]. Mirovaya ekonomika i mezhdunarodnye otnosheniya, (9), 54-65. (In Russ.)

Reshoring Initiative USA. (2019). Reshoring initiative: Bringing manufacturing back home. Retrieved from http://www.reshorenow.org (accessed: 20.12.2019).

Savinov, Y.A., Zelenyuk, A.N., Taranovskaya, E.V., Orlova, G.A., \& Skurova, A.V. (2019). Usilenie protekcionizma vo vneshnej torgovle SSHA [Strengthening Protectionism in US Foreign Trade]. Russian Foreign Economic Bulletin, (1), 36-51. (In Russ.)

Srai, J.S., \& Ané, C. (2016). Institutional and strategic operations perspectives on manufacturing reshoring. International Journal of Production Research, 54(23), 7193-7211.

Stentof, J., Olhager, J., Heikkilä, J., \& Thoms, L. (2016). Manufacturing backshoring: A systematic literature review. Operations Management Research, 9(3-4), 53-61.

Zagashvili, V.S. (2017). VTO i megaregional'nye torgovye soglasheniya [WTO and megaregional trade agreements]. Russian Foreign Economic Bulletin, (5), 27-37. (In Russ.) 
Article history:

Received: 15 November 2019

Revised: 23 December 2019

Accepted: 10 January 2020

\title{
For citation:
}

Chernova, V.Yu. (2020). Reshoring to the EU and the USA: Problems, trends and prospects. RUDN Journal of Economics, 28(1), 160-171. http://dx.doi.org/10.22363/23132329-2020-28-1-160-171

\section{Bio note:}

Veronika Yu. Chernova, Candidate of Economic Science, Associated Professor, The State University of Management; marketing manager, EDP Danone. E-mail: veronika_urievna@ mail.ru

\section{Научная статья}

\section{Решоринг в страны ЕС и США: проблемы, тенденции и перспективы}

\author{
В.Ю. Чернова \\ Государственный университет управления \\ Российская Федерачия, 109542, Москва, Рязанский просп., 99
}

В настоящее время решоринг признан одним из средств достижения поставленной в западных странах цели восстановления роли обрабатывающей промышленности в экономике, ее «ренессанса», стимулирования инноваций и роста занятости. В статье проанализированы современные тенденций и перспективы решоринга. Выявлены препятствия успешной релокации производственных мощностей западных компаний в материнскую юрисдикцию, ключевая роль среди которых принадлежит протекционистской политике США и эскалации торговых конфликтов. В результате после роста числа случаев решоринга в предшествующие годы в 2018-2019 гг. процесс перемещения производственных мощностей западных компаний в другие страны Юго-Восточной Азии с более низкими издержками получил дополнительный импульс. Сделан вывод о том, что государственные политики стран, направленные на возрождение своей промышленности и технологии четвертой промышленной революции, оказывают заметное влияние на изменение позиции отдельных стран в системе международного разделения труда, что дает шанс «догоняющим странам» для развития экономики и улучшения своих позиций в мировой торговле.

Ключевые слова: решоринг, реиндустриализация, цепочки добавленной стоимости, технологии четвертой промышленной революции, протекционизм, торговые войны, торговая политика, меры содействия стратегиям решоринга

\section{История статьи:}

Дата поступления в редакцию: 15 ноября 2019

Дата проверки: 23 декабря 2019

Дата принятия к печати: 10 января 2020 


\section{Для цитирования:}

Chernova V.Yu. Reshoring to the EU and the USA: problems, trends and prospects (Решоринг в страны ЕС и США: проблемы, тенденции и перспективы) // Вестник Российского университета дружбы народов. Серия: Экономика. 2020. Т. 28. № 1. C. 160-171. http://dx.doi.org/10.22363/2313-2329-2020-28-1-160-171

\section{Сведения об авторе:}

Чернова Вероника Юрьевна, кандидат экономических наук, доцент, Государственный университет управления; менеджер по маркетингу, EDP Danone. E-mail: veronika urievna@mail.ru 